Bayero Journal of Pure and Applied Sciences, 5(1): $84-89$

Received: October 2011

Accepted: April 2012

ISSN $2006-6996$

\title{
APPRAISAL OF THE ECONOMIC ACTIVITIES OF TERMITES: A REVIEW
}

\author{
*Ibrahim, B. U. and Adebote, D. A. \\ Department of Biological Sciences, Faculty of Science, Ahmadu Bello University, Zaria, kaduna state \\ *Correspondence author: ibrahimsayuti@yahoo.com
}

\begin{abstract}
Termites can be found through out the world largely in the tropical and sub-tropical countries. They are social insects, feeding on cellulosic materials and live in colonies. Termites comprise the Order Isoptera with six families, 170 genera and 2600 species, of which six species are present in Nigeria. The most striking aspects of termites is their destructive tendency. They feed on wood indiscriminately, and tend to destroy timber and other wooden materials of importance to man, and this brought them into direct competition with man. However, their beneficial aspect to man is very significant. In most countries, where termites exist in abundance they are edible. Their burrowing within the soil increases the rate of percolation of water into the soil, thereby promoting water absorbent of the soil. Their feeding habit includes decomposition of dead trees, and incorporation into the soil, mineral nutrients of these trees. Man in response to the destructive activities of termites, developed various controlled methods towards them, which include the use of pesticides such as DDT ( Dichloro Diphenyl Trichloroethane), BHC ( Benzene Hexachloride ), Aldrin, Dieldrin, soil barrier termiticides, treated zone termiticides, dust and fumigant, and, non chemical control methods such as mud tube removal, debris removal, pathogenic fungi, mechanical barriers, heat, high voltage electricity or electrocution and wood replacement. The control of termites however, does not seek to totally exterminate them, but to bring their activities to a manageable level. The objective of this paper is to appraise the economic activities of termites.
\end{abstract}

Keywords: Economic activities, pesticides, social insects, Termites.

\section{INTRODUCTION}

Termites are social insects living in colonies. They are sometimes called white "ants", however they are not ants, because the true ants belong to the Order Hymenoptera, while termites belong to the Order Isoptera (Grimaldi and Engel, 2005). Engel and Krishna (2004), grouped termites into 6 families, 170 genera and about 2600 species, of which 300 species are said to be of economic importance. Termites can be divided into three general categories based on their habitat: damp wood, dry wood and subterranean (Paul and Rueben, 2005). According to Paul and Rueben (2005), damp wood termites do not present wide spread pest problems, but can be problematic under certain conditions, dry wood termites are significant and costly pests, while the subterranean termites are the major urban pests.

The interaction of termite with man arises as a result of man's interference with natural food supply of termite and with its environment (Edwards and Mill, 1986). However, since their food supply is mainly wood and woody tissues of plant, they do come into direct competition with man resulting in great loss of properties and amenities. Although, the destructive activities of termites has been natural, their beneficial activities on the other hand include the production of organic matter from dead wood and woody tissues of plants, and thereby restore organic matter to the soil and air (Ohiagu, 1979). They are also utilized as food by various animals including man, and they are of highly nutritive value (Harris, 1970).

The destructive activities of termites as a result of their feeding habits cannot be over emphasized. It includes the damages done to agricultural crops such as cash crops and food crops (Harris, 1961; Abe et al., 2000), timbers in buildings, post, fences, damages to clothes, books, underground cables and air fields, earth dams and irrigation canals. They also reduce watering retaining capacity of the soil, by removing the plant cover and thus promote erosion to some extent (Lee and Wood, 1971). The damages done to all these articles are great and amount to millions of naira.

Despite the destructive activities of termites to man, their beneficial effects are enormous (Ahmad and Yaacob, 1997). The material of the mound is eaten by the primitive tribes, this may be due to mineral salts present, and they also used it to feed their chickens (Howse, 1970). Termites mound materials which is very fine can be made hard and used in making roads, tennis courts, bricks use in building, and also used as a source of pottery clay (Su and Scheffrahn, 2000; Edwards and Mill, 1986). The aim of this paper is to appraise the economic activities of termites as a review, in relation to their interaction with man.

\section{Biology of Termites}

Termites live in a true social group with a division of labour among the different caste of individuals: reproductive adults, soldiers and workers (Noirot, 2000). Termites have a complex life cycle with the development of individuals that look and behave differently from other members of the group. 
According to Edwards and Mill (1986), there are three general developmental stages: egg, immature and adult in termite's life cycle known as incomplete metamorphosis. The role of the winged adult is dispersal and reproduction, the actual work of the colony and expansion of the colony's foraging is done by the caste of workers, while the soldiers defend the colony (Forschler and Jenkins, 2000). Winged adults (alates or swarmers ) represent a primary caste of individuals within the termite colony. They disperse from their colony of origin in a series of flights or swarms at precise time of the year. Adults are attracted to lights, where pairing begins. The swarmers on reaching the ground shed their wings and started searching for a suitable place to initiate a colony. The males are attracted to the females by a scent or pheromone. They dig into the wood or moist soil depending on the species and form a chamber. Mating occurs within the nuptial chamber, and the queen once fertilized, initiates the new colony as she begins to lay eggs.

\section{Ecology of Termites}

Termites are a highly successful group of true social animals, as evidence by their worldwide distribution and evolutionary persistence (Paul and Rueben, 2005). They serve an important ecological role in the decomposition of cellulose materials that cannot be chemically broken down without the present of the enzyme, cellulose (Pearce, 1997). According to Bignel (2000), primitive termites do not produce sufficient cellulase for survival, but contain protozoans in their gut that aid in cellulose breakdown. This interaction is an obligate mutualism for both termite and protozoan (Bignell, 2000). Higher termites (Termitidae) do produce sufficient cellulase in their mid gut to digest adequate nutrition from cellulose, but still form mutualism with both bacteria and fungi biota ( Abe et al., 2000). Under natural conditions in the desert, termites feed on dead plant materials, including roots, leaf litters, grass, cactus skeletons, dungs and humus (Jones and Nutting, 1989). According to Su and Scheffrahn (1990), although the feeding activity of termites is critical to the recycling of nutrients in the ecosystem, unfortunately they infest human - made structures and damage lumber, sheetrock , wallpaper, wood panel and furnitures. Termites spend their entire life in soil or within their source of food, and once removed from their protected environment and favourable humidity, they die (Edwards and Mill, 1986). According to Lee (2002), termites do not feed on concrete, stucco, fiberglass insulation or other non organic materials. However, they can damage these materials and use them to line and support their shelter tubes. Termites can be categorized based on habitat: damp wood, dry wood and subterranean. Damp wood and dry wood can be pest under certain situations. The damp wood termites Paraneotermes simplicicornis (Banks) require more wood moisture than is provided by ambient humidity. Under natural conditions, they are restricted to moist wood in contact with the damp soil (Light, 1994). The dry wood termites are pests of sound dry structural lumber or wood furniture. They require no contact with the soil and live entirely within their food source (Su and Scheffrahn, 2000). The subterranean termites is the most widespread and destructive group. They derived their name subterranean termites because of their association with the soil. They construct underground tunnels to move about in search of food. Subterranean termites can be pervasive pest and account for about $80 \%$ of loses to wooden structures, Reticulitermes tibialis (Banks), Heterotermes aureus (Synder), Amitermes wheeleri (Desenex) and Gnathamitermes perplexus (Banks) (Potter, 1997; Su and Scheffrahn, 1998).

\section{Economic Activities of Termites Destructive Effects of Termites}

The destructive effects of termites to man, whenever they interact with each other is very enormous. It includes the damages done to the timbers used in buildings and for other purposes (Su and Scheffrahn, 2000; Sornnuwat, 1996). Lee and Wood (1971), Pearce (1997), and Ahmad and Yaacob (1997) reported that some of the termites species involved are the soil inhabitants. Harris (1961) reported that the Building Research Institute, Accra suggested the annual cost of repairing buildings damage by termite in West Africa was $10 \%$ of their capital cost. Termite's effects are damaging, costing the Southern United States approximately $\$ 1.5$ billion each year in wood structure damage (http:// www. ars. Usda.gov/is/pr/2010/100217.htm). In addition to the attacks on buildings, termites also damage man made fabrics (textile materials), plastics ( polytene, polyvinyl chloride), and some metal foils (Howse, 1970). Therefore, this economic importance extends to countries like Britain which import from termite infested zone. According to Harris (1970); Cowie et. al., (1989) termites promote loss of soil by erosion, by removing the plant cover, thus exposing the soil surface to erosive forces. Harris (1971), reported that damages to earth dams have been documented and also to irrigation ditches.

Termites are among the most important insect pests in certain forest and many of the destructive species live in the soil, for example the species that cause most damages in Ausralian forest, Coptotermes acinaciformis is a soil inhabitant (Gay and Galaby, 1970). The economic loss may be great as Gay and Galaby (1970) estimated in Virgin Eucalyptus pilularis, forest termite Coptotermes acinaciformis caused $92 \%$ of the total loss. Harris (1970), reported that in parts of Africa damages to trees are common, however the introduced trees particularly Eucalyptus species are severely attacked. In April 2011, wood - eating termites were reported to have consumed more than $\$ 220,000$ worth of Indian rupee notes (http://articles. nydailynews.com).

Ohiagu (1979), gives a lot of information on termite as a major pest in Nigeria. The major termite pest species is Macrotermes. This termite lowers yield of plants in light soils with low moisture. Estimates of loses reported from various locations in the northern states of Nigeria ranges from $5-18 \%$. The areas involved are Samaru (Kaduna State), Bakura (Sokoto State) and Hadeija (Jigawa State). 
Ohiagu (1979) also reported damage done by termites to three major cereals crops, maize, millet and Sorghum in various parts of Northern Nigeria. Harris (1971), reported that Macrotermes bellicosus attack the root of seedlings in Nigeria, while Macrotermes subhyalinus cut the stems of rice as the plant ripen and this causes loses from $15-20 \%$ per plot. Sands (1962) reported $40 \%$ yield loss of cassava due to termites attack in Nigeria, and the species involved are Pseudo canthotermes, Odontermes, Ancistotermes and Nucrotermes.

Mounds formed by termites make proper preparation of fields for cultivation difficult, they also interferes with traffic, if formed on the tracks or along the roads. The mounds can also form a source of termite infestation of field crops (Reddy, 1960; Piper, 2007). Termites cause denudation of grass land, they even compete with livestock in the removal of grass. Ohiagu (1979) in Nigeria reported a grass removal rate of about $81 \mathrm{Kg}$ per hectare per annum for Trinervitermes germinatus at Mokwa.

\section{Beneficial Aspects of Termites}

In spite of the destructive activities of termites, man should not look upon termite as being totally harmful, they too have their place and uses within the environment, where they exist (Abe et al., 2000). Chatterjee (1972) and Eggleton (2007), stated that among the beneficial aspect of termite is decomposition, they cause to dead wood in the forest, which would have pile up and suffocate young plants, and through the decomposition they increase mineral component of the soil, by introducing into the soil mineral nutrients of the dead woods, also the burrowing they made in the soil increase water absorbent of the soil.

Harris (1961) reported that termite mounds have been used in making bricks for building, pottery, for plastering walls and for surfacing roads and pavements. The hard materials of the mound are also used in making tennis courts. Lee and Wood (1971), reported that termite mound material is useful in construction of ovens.

Termite has been considered as a source of energy. Termite can produce up to two litres of hydrogen from digesting a single sheet of paper, making them one of the planets most efficient bioreactors (http://www.animalpicturesarchive.com). Termites achieve this high degree of efficiency by exploiting the metabolic capabilities of about 200 different species of microbes that inhabit their hindgut. The microbes in the termites gut efficiently manufacture large quantities of hydrogen, the complex lignocellulose polymers within the wood are broken down into simple sugars by fermenting bacteria in the termite's gut, using enzymes that produce hydrogen as a bye product (http://www.animalpicturesarchive.com).

Termites themselves have been used as food in certain parts of the world. In countries where termites are found in large numbers, the inhabitants capture the flying forms for food. The Alate termites are nutritious, with a good store of fats and protein (Engel and Krishna, 2004). Ene (1963), reported that
90.6\% Alate termites are eaten by people in West Africa. Termites tend to form a useful source of animal protein in places where meat is scarce (Harris, 1971). Harris (1971), also reported the composition of roasted flying termite to be Ash $6.42 \%$, Fat $44.40 \%$, Protein $36.0 \%$, Chitin $5.09 \%$, and 560 per hundred grammes caloric value.

Termites serve as ecological indicator. Termite knolls has been used as an indicator of underground water, also a well developed, active, permanent colony of mound - building termites has been considered as an indicator of underground springs in proximity e.g. include termitarium seen in Katanga province of Congo Kinshasha, right up to the hill slopes where springs emerge, and in the dry jungle uplands of coastal zone of Karnataka State (Old Mysore State) in India (IHP, 1990). Termites are important in habitat formation as shown in their role in hollowing timbers and thus providing shelter and increased wood surface area for other creatures. Large termite mould play a significant role in providing habitat for plants and animals, such as smaller animals and birds, and a growing medium for woody shrubs with root system that cannot withstand inundation for several weeks (http://www.aseanbiodiversity.info/abstract/53002297 .pdf).

Few zoos hold termites in captivity, due to the difficulty in keeping them captive and the reluctance of the authorities to permit potential pests e.g. Zoo Basel in Switzerland hold two African termites (Macrotermes bellicosus). Their populations exist and thrive.

(http://www.nzz.ch/nachricten/panorama/in_zoo_base I_fliegen_die_Temiten_aus_html).

Termites serve as a source of income to people wherever they exist, for instance termites are commonly sold in Tropical African markets and they can also be pressed to extract cooking oil (Ene, 1963). The large population of termite nests are collected by inhabitants in rural areas, and used as poultry feeds, especially for domestic fowls, thereby making their flesh more delicious (Harris, 1961; Marthur, 1960).

\section{Control of Termites}

The menace of the activities of termites is enormous, therefore there is need to control the activities of termites, so as to bring their activities to a manageable level. The control of termites involves non - chemical and chemical control methods.

\section{Non - chemical Control Methods}

This is an alternative to chemical control of termites (i.e. to control active infestation), which involves a long term measures and focus on prevention.

\section{Mud Tube Removal}

Removing the tube provide a method to determine if termite infestation remains active after treatment or if the termites reappear in the same area later. Scraping away mud tube as the sole means of control, may not be possible and probably unwise in many cases, such as with slab construction, where much of the termite activity is inaccessible. The tubes are an indication that termites are active around the house. 


\section{Debris Removal}

This method involves the removal of cellulose debris. Removing the debris help reduce food resources that could be used by termites. Thus, items made up of wood, cardboard or paper, which can serve as food for termites should be removed from the building premises. Also tree stumps that are left under houses during construction should be removed.

\section{Pathogenic Fungi}

This is a biological control method of termites. Termites dwell in an environment that contains microorganisms, including many that are lethal to them. One of these pathogenic fungi, Metarhizium anisophiliae has been developed commercially into a product called Bioblast $\AA$. This product which contains fungal spores is applied to accessible termites' infestations above ground. The spores germinate and the fungus penetrates the insect cuticle (i.e. the outer skin). The fungus grows inside the insect's body and eventually kills it. Infected termites that come into contact with other members of their colony can mechanically transfer the fungus to them.

\section{Mechanical Barriers}

In this control method, termites - resistant building materials are used during construction. These materials are most easily installed in new construction, however some materials can be fit to existing houses, although the cost may be significant.

\section{Heat}

Heat is a non chemical option for whole structure treatments. Excessive heat kills dry wood termites by disrupting cellular membranes and denaturing enzymes needed for their survival. The treatment process involves heating all wood in the structure to a minimum of $120^{\circ} \mathrm{F}$, and holding this temperature for at least 33 minutes. The advantage of this method is the ability to treat the entire structure without the use of chemical, and the relatively short period of time the structure must be vacated, hours instead of days, as with the use of fumigants. Due to the development of more powerful and efficient heaters, larger homes can be efficiently treated with heat.

\section{High Voltage Electricity or Electrocution}

This is a non chemical method for controlling dry wood termites. The device uses high voltage $(90,000$ volts) but low currents (less than 0.5 amps). The dry wood termites died as a result of electric shock, delayed mortality may occur due to the destruction of intestinal protozoa. The limitations in this method, include detection accuracy and the possible reduced efficacy from the interfering actions of common building materials e.g. metals, concrete and glass.

\section{Wood replacement}

The effectiveness of wood replacement as a control method for termites is highly dependent on detection accuracy, the extent and location of the infestation. Wood replacement may be expensive to accomplish.

\section{Chemical Control Methods of Termites Soil Barrier Termiticides}

This method involves creating a chemical barrier in the soil, which is toxic to termites contacting it. Many also have repellent characteristics. The effectiveness of the termiticides over a long period of time is achieved when applied as a continuous barrier in the next to and under the foundation. If there are untreated gaps in the soil, termites may circumvent the chemical treatment. Therefore, treatment during preconstruction, provide more uniform coverage. Termiticides that act by creating a chemical barrier in the soil include Bifenthin ( Talstar $®)$ ), Cypermethrin (Demon $\AA$, Prevail $\AA$ ), and, Permethrin (Dragnet $\AA$, Prelude $($ )).

\section{Treated - Zone Termiticides}

This termiticides are non- repellent to termites, but show delay toxicity as termite forage through the treated soil, which they do not avoid. The termites contact the active ingredient as they penetrate the "treated zone", which causes delay mortality and also allow the termites to be overcome by lethal microbes. The toxicant is passed to the nest mates through grooming activities and social food exchange (trophallaxis). The control is usually achieved within 3 months. The non-repellent termiticide include Fipronil (Termidor $®)$, Imidacloprid (Premise $\circledR$ ) and Chlorfenapyr (Phantom $®$ ).

\section{Dust}

Dusts can be used as stand alone treatments or as a part of a combined approach. The dust settles on the termites, which then carry the dust back to the nest. The termites clean themselves of the dust and ingest the active ingredient. The active ingredients is spread through out the colony, through grooming which is a social activity by the termite. If enough active ingredient is ingested, then it is possible to eliminate the entire colony. The active ingredients in the dust may include: Arsenic trioxide, Fipronil and Triflumuron. Scheffrahn et al. (2001), reported that newly established colony of drywood termites Cryptotermes brevis could be prevented using dust formulations of commercially available disodium tetrahydrate.

\section{Fumigants}

Fumigants (e.g. Sulfuryl fluoride) treated all infestations simultaneously and have high level of efficacy, if correctly applied. Sulfuryl fluoride kill the dry wood termites in about 3 days. Fumigation advantage over localized treatment is that it may eliminate infestations that are hidden from view. It is necessary to vacate the structure $2-3$ days, while it is being treated and then ventilated.

\section{Bait}

Bait technology uses wood or cellulose matrix favoured by termites that is impregnated with a slowacting toxic chemical as active ingredient. Termite workers feed upon the bait and transfer it by grooming activities and social food exchange (trophallaxis) to other colony members, eventually reducing or eliminate the entire colony. Bait system can be applied as stand alone treatments, or as part of a combined approach. 
Bait products that are available include Sentricon $(\AA$ Termite colony elimination system (hexaflumuron, Recruit ${ }^{\circledR}$ II bait), firstline ${ }^{\circledR}$ Termite defence system (Sulfluramid), subterfuge $\mathbb{R}$ Termite bait (hydramethylnon) and outpost ${ }^{\circledR}$ Termite Bait Response (diflubenzuron).

\section{Advanced Researches on Termites}

In order to better control the population of termites researcher at the Agricultural Research Service in U.S.A. in 1990, discovered a way to track the movement of the destructive termites, safely and reliably, using immunoglobulin G (IgG) marker proteins from rabbits or chickens. This method of testing for the tracking protein is expensive. New methods of tracking termites developed recently and less expensive use egg white, cow milk, or soy milk proteins, which can be sprayed on termites in the field. The protein can be traced using a protein specific ELISA (http://www.pnas.org.cgi/content/full/99/23/14887; http//www.arsda.gov./is/pr/2010/100217.htn). The U.S. Department of Energy is researching into methods of replacing fossil fuels with renewable sources of clearer energy, of which termites are considered a possible way to achieve this goal through metagenomics (http://www.jgi.doe.gov). Thus, by sequencing the termite's microbial community, the U.S. Department of Energy intends to get a better understanding of these biochemical pathways. If the enzymes that are used to create hydrogen can be determined, and, which genes produce them. This process could potentially be sealed up with bioreactors to generate hydrogen from woody biomass, in commercial

( http://www.jgi.doe.gov/education/bioenergy 4.html).

Recent research with classical enrichment culture technique and metagenomic approach showed that termites and their symbionts are potentially good resource of functional genes for industrial applications (Matsui et al., 2009). According to Matsui et al.(2009), recent papers and publications showed that termites and its symbionts have not only cellulolytic or lignin decomposition activity, but also aromatic hydrocarbons degradation. These functions would be useful for biomass utilization, environmental remediation and fine-chemical productions.

\section{REFERENCES}

Abe, T., Bignell, D.E., and Higashi, M. (2000). Termites: Evolution, Socially, Symbioses, Ecology. Kluwer Academic Publishers. 256pp.

Ahmad, S. S and Yaacob, A.W. (1997). Termites from Selected Building Premises in Selangor Peninsular Malaysia. Malaysian Forester 60: $203-215$.

Bignell, D. E. (2000). Introduction to symbiosis. In: Termites: Evolution, Sociality and Ecology. Kluwer Academic Publishers, Dordrecht, The Netherlands. 189 - 208pp.
Physical barrier has become popular worldwide as a method of preventing attacks on structures by subterranean termites. According to Julian et al.(1999), research has shown that ground termites have difficulty in penetrating layers of certain granular materials, depending on the material's physical size, smoothness, shape, weight and hardness. Research involving extensive laboratory and field tests found that crushed, screened basaltic gravel is suitable as a barrier to the Formosan subterranean termites, with the material marketed as the basaltic termite barrier (BTB) Julian et al., (1999).

\section{Conclusion and Recommendations}

The role and the need for the fundamental control of termite is emphasized, however the control methods should be employed to bring their activities to a manageable level, rather than totally exterminating them. Therefore, the existing insecticides should be used correctly to minimized damages done by termites.

People in the rural areas and towns should be educated on activities of termites and their control methods either through mass media like radio or by publishing pamphlets. Government should make available insecticides to the rural areas at subsidized price, so that the inhabitant can obtain them, because if termites can be controlled in rural areas, their activities can be brought to a manageable level, and this will also reduced their spread to towns and cities.

Timbers to be used in building should be properly treated with chemicals, as a preventive measure against termite attack. When building is to be erected in an highly infected area, the soil should be treated first with chemicals to eradicate the termites, before the building is erected.

Proper construction techniques, such as isolating wood from the soil, and the use of physical barrier to exclude subterranean' termites, are practical approaches to preventing termites attack on structures. Further researches on the inhibitors of cellulose digesting enzymes in termites and the microbial activities of protozoan digesting cellulose in termites in the laboratory are recommended. These can then be used to synthesis simple sugar from wood.

Chatterjee, P.N.(1972). Role of Termites in Forestry. In: Termite problems in India. 4 - 7pp.

Cowie, R.H., Logan, J.W.M. and Wood, T. G. (1989). Termite (Isoptera) Damage and Control in Tropical Forestry with Special Reference to Africa and Indo-Malaysia: A Review. Bulletin of Entomological Research 79: 173 - 184.

Edwards, R. and Mill, A.E. (1986). Termites in Buildings. Their Biology and Control. Rentokil Ltd., West Sussex, U.K. $54-67 p p$.

Eggleton, P. (2007). Biological Letters, June 7, cited in Science News Vol. 171, p. 318.

Ene, J. C. (1963). Insect and Man in West Africa. Cambridge University Press Pp. 16-19, 42-47. 
Engel, M.S. and Krishna, K. (2004). "Family-group names for Termites (Isoptera)". American Museum Novitates 3432: 1-9.

Forschler, B. T. and Jenkins, T. M. (2000). Subterranean Termites in the Urban Landscape: Understanding their social structure is the key to successfully implementing population management using bait technology. Urban Ecosystems 4: 231 - 251pp.

Gay, F.J. and Galaby, T.H. (1970). Termites for the Australian Region. In: Biology of Termites (Krishna. K. and Weeser F.M.) Vol. 2, 393-448 pp.

Grimaldi, D. and Engel, M.S. (2005). Evolution of the Insects. Cambridge University Press. 145pp.

Harris, W.V. (1961). Termites: Their Recognition and Control. Tropical Agric. Series. pp 30-34, 53-64.

Harris, W.V. (1970). Termites of the Palearctic Region. In: Biology of Termites (K. Krishna and F.M. Weesner). Vol. 2: 295-313.

Harris, W.V. (1971). Termites: Their Recognition and Control. Tropical Agric. Series. pp 30-34, 53-64.

Howse, P.E. (1970). Termite: A Study in Social Behaviour. Rentokil Ltd. West Sussex, U. K. pp. 25-29, 163176.

International Hydrological Programme (IHP) (1990). Hydrology in Ancient India. National Institute of Hydrology Publication , Roorkee, India. 58 60pp.

Jones, S.C. and Nutting, W. L. (1989). Foraging Ecology of Subterranean Termites in the Sonoran Desert. In: Special Biotic Relationships in the Arid Southwest. University of New Mexico Press, Albuquerque, N.M. $79-106 \mathrm{pp}$.

Julian, R.Y., Kenneth, G.J. and Minoru, T. (1999). New Technology for Managing the Formosan Subterranean Termite. University of Hawaii Publications. Manoa. $52-58 p p$.

Lee, C. Y. (2002). Subterranean Termite Pest and their Control in the Urban Environment in Malaysia. Sociobiology 40: $3-9$.

Lee, K. E. and Wood, T. G. (1971). Termites and Soils. CABI Publishing. New York, N.Y. Pp. 1-24, 65-71.

Light, S. F. (1994). The Damp- Wood Termite, Paraneotermites simplicicornis. In: Termites and Termite Control. University of California Press, Berkeley, C. A. 311 - 313pp.

Marthur, R.N. (1960). Enemies of Termites (White Ants). In: Termites of the Humid Tropics. Proceedings of the New Delhi UNESCO. Pp. 137139.

Matsui, T., Tokuda, G. and Shinzato, N. (2009). Termites as Functional Gene Resources. Biotechnol. 3 ( 1) : $8-10$.

Noirot, C. (2000). Formation of Castes in the Higher Termites. In: Biology of Termites. Vol. 1. Academic Press, New York, N. Y. 311 - 350pp.

Ohiagu, C.E. (1979). Nest and Soil population of Trinervitermes Spp. with particular References to Trinervitermes germinatus (Wasmann) Isoptera in Southern Guinea Savanna, near Mokwa, Nigeria. Ecologia 40 : 167-178.

Paul, B. B. and Rueben, J. M. (2005). Arizona Termites of Economic importance. University of Arizona Press, Tucson, AZ. 9 - 17pp.

Pearce, M. J. (1997). Termites: Biology and Pest management. CABI Publishing. New York, N.Y. 86 $-92 \mathrm{pp}$.
Piper, R. (2007). Extraordinary Animals: An Encyclopedia of Curious and Unusual animals. Greenwood Press. 125pp.

Potter, M. F. (1997). Termites. In: Mallis Handbook of Pest control, $8^{\text {th }}$ Ed., Mallis Hand book and Technical Training Company, Cleveland, Ohio. 63 -68pp.

Reddy, D.B. (1960). Termites in Relation to Agriculture. In: Termites of the Humid Tropics. Proceedings of the New Delhi UNESCO. Pp. 225.

Sands, W.A. (1962). The Evaluation of Insecticide as Soil and Mound Poisons against Termites in Agriculture and Forestry in West Africa. Bull. Ent. Res. 53: 179-192.

Scheffrahn, R.H., Su, N. Y., Krecek, J., Liempt, A.V., Maharajh, B. and Wheeler, G.S. (2001). Prevention of Colony Foundation by Cryptotermes brevis and Remedial Control of Dry Wood Termites ( Isoptera kalotermitidae ) with selected chemical treatment. J. Econ. Entomol. 91 ( 6 ) : 1387 - 1396.

Sornnuwat, Y. (1996). Studies on Damage of Constructions caused by Subterranean Termites and its Control in Thailand. Wood Research No. 83

Su, N.Y. and Scheffrahn, R. H. (1990). Economically important Termites in the United State and their Control. Sociobiology 17: $77-94$.

Su, N.Y. and Scheffrahn, R. H. (1998). A Review of Subterranean Termites Control Practices and Prospects for Integrated Pest Management. Integrated Pest Management Review 3: 1 $-13$.

Su, N.Y. and Scheffrahn, R. H. (2000). Termites Aspects of Buildings. In: Abe, T. Bignell, D.E. and Higsahi, M. eds. Termites : Evolution, Sociality, Symbiosis and Ecology. Kluwer Academic Dordrecht, The Netherlands. 437 - 453pp.

http://www. animalpicturearchive.com/view.php/28077. Termite (Order: Isoptera) accessed 16 - 09 2011.

http//www.arsda.gov./is/pr/2010/100217.htn accessed $18-09-2011$.

http://www.ars.usda.gov/is/pr/2010/100217.htm accessed $16-09-2011$

http://www.articles.nydailynews.com/2011-0425/news/29492144_1_rupee_state_bank_termites . accessed $16-09-2011$

http://www.aseanbiodiversity.info/abstract/53002297.pdf ) accessed 16-09-2011

http:// www. jgi.doe.gov.Organisation responsible for sequencing the termite accessed $20-09-2011$.

http://www.jgi.doe.gov/education/bioenergy 4.html.Original article on termite as bioreactors. accessed $20-09-2011$.

http://www.nzz.ch/nachrichten/panorama/im_zoo_basel_ fliegen_dietermiten_aus_1.848530.html. (German). In zoo Basel fliegen dieTermiten $1848530 \mathrm{html}$ accessed $16-09-2011$.

http:// www. pnas.org/cgi/content/full/99/23/14887. The evolution of fungus - growing termite and their mutualistic fungal symbionts .By Duur K. A., Paul,E ., Corinne, R.L., Tbias, G. F. Soren, R. and Jacobus, J.B. accessed $20-09-2011$. 